\title{
Ammonia and Methane Emission Factors from Cattle Operations Expressed as Losses of Dietary Nutrients or Energy
}

\section{Zifei Liu *, Yang Liu, James P. Murphy and Ronaldo Maghirang}

Department of Biological and Agricultural Engineering, Kansas State University, Manhattan, KS 66056, USA; yliu16@k-state.edu (Y.L.); jmurphy@k-state.edu (J.P.M.); rmaghir@ksu.edu (R.M.)

* Correspondence: zifeiliu@ksu.edu; Tel.: +1-785-532-3587

Academic Editor: Ryusuke Hatano

Received: 15 December 2016; Accepted: 20 February 2017; Published: 23 February 2017

\begin{abstract}
The objective of this study was to conduct a systematic review of published literature on ammonia $\left(\mathrm{NH}_{3}\right)$ and enteric methane $\left(\mathrm{CH}_{4}\right)$ emissions from beef and dairy cattle operations to obtain statistically representative emission factors based on dietary intakes of nutrients or energy, and to identify major causes of emission variations. $\mathrm{NH}_{3}$ emissions from lagoon or other manure storage facilities were not included in this review. The $\mathrm{NH}_{3}$ and $\mathrm{CH}_{4}$ emission rates, expressed as a percentage losses of dietary nutrients or energy, demonstrated much less variation compared with emission rates expressed in g/animal/day. Air temperature and dietary crude protein $(\mathrm{CP})$ content were identified as two major factors that can affect $\mathrm{NH}_{3}$ emission rates in addition to farm type. Feed digestibility and energy intake were identified as two major factors that can affect $\mathrm{CH}_{4}$ emission rates expressed as a percentage losses of dietary energy. Generally, increasing productivity and feed efficiency represented the greatest opportunity for mitigating $\mathrm{NH}_{3}$ or $\mathrm{CH}_{4}$ emissions per unit of livestock product. Expressing $\mathrm{CH}_{4}$ loss on a digestible energy basis rather than a gross energy intake basis can better represent the large variation among diets and the effects of varying dietary emission mitigation strategies.
\end{abstract}

Keywords: crude protein content; feeding efficiency; nitrogen; forage-to-concentrate ratio; digestibility; digestible energy; feed intake; $\mathrm{NH}_{3}$ and enteric $\mathrm{CH}_{4}$ emissions

\section{Introduction}

Beef and dairy cattle operations emit gases into the atmosphere from animal feed digestion (enteric fermentation) and manure decomposition. Ammonia $\left(\mathrm{NH}_{3}\right)$ is produced as a by-product of the microbial decomposition of the organic nitrogen $(\mathrm{N})$ compounds in manure, and has been listed as one of the most important atmospheric species emitted from livestock operations in the U.S. due to its impact on ecosystems and air quality concerns [1]. Enteric methane $\left(\mathrm{CH}_{4}\right)$ is produced by ruminants as a result of microbial breakdown of carbohydrates in the rumen, and enteric $\mathrm{CH}_{4}$ emissions from cattle operations are considered a major contributor to greenhouse gas (GHG) emissions in the U.S. [2]. In addition to environmental concerns, $\mathrm{NH}_{3}$ emissions represent an unproductive loss of dietary nutrients. The fertilizer value of manure is reduced due to $\mathrm{N}$ volatilization to the atmosphere as $\mathrm{NH}_{3}$. Similarly, $\mathrm{CH}_{4}$ emissions represent an unproductive loss of dietary energy (Figure 1). The U.S. Environmental Protection Agency (EPA) estimated that more than $80 \%$ of human-induced $\mathrm{NH}_{3}$ emissions in the U.S. come from livestock production, in which beef and dairy cattle contributed more than half [3]. Enteric fermentation and manure management of livestock production are responsible for $2.2 \%$ and $1.1 \%$ of the total human-induced GHG emissions in the U.S., respectively, and cattle operations are considered the major contributors within the various livestock species [2]. 


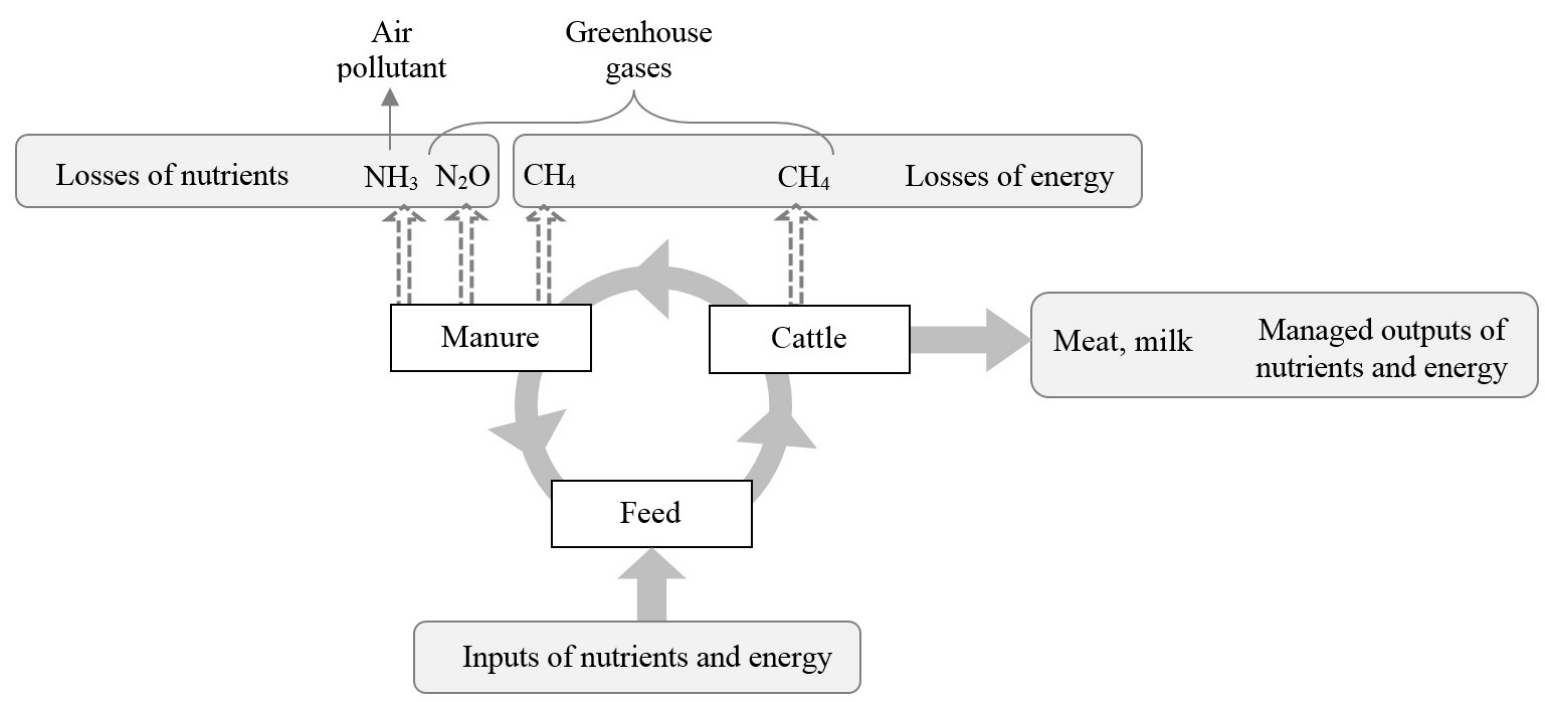

Figure 1. Gas emissions represent losses of nutrients and energy from cattle operations.

With increasingly stringent air pollution regulations and the emerging pressure to regulate agricultural enterprises, there will be a continued need for emission inventories based on reliable and representative emission factors, as well as an increasing demand for mitigation strategies. On the other hand, production efficiency is a contributing factor in reducing the environmental footprint per unit of product. Strategies that increase production efficiency will conserve resources and improve environmental stewardship, and could represent a great opportunity for mitigating $\mathrm{NH}_{3}$ and $\mathrm{CH}_{4}$ emissions per unit of livestock product. In evaluating these mitigation practices, quantifying $\mathrm{NH}_{3}$ and $\mathrm{CH}_{4}$ emissions as a percentage of losses of dietary nutrients or energy would be beneficial. In addition, emission factors based on intakes of dietary nutrients or energy can address the effect of feed intake and reduce uncertainties in estimation of emissions, and also be used as a key parameter in establishing emission inventories. Various emission models have been developed to simulate $\mathrm{NH}_{3}$ and $\mathrm{CH}_{4}$ emissions from beef and dairy cattle operations. Most of the current empirical or statistical models are built from data collected under controlled conditions or from a particular site, and care must be taken when generalizing these models to estimate emissions under different scenarios.

The objective of this study was to conduct a systematic review of published literature on $\mathrm{NH}_{3}$ and $\mathrm{CH}_{4}$ emissions from beef and dairy cattle operations in order to obtain statistically representative emission factors based on intakes of dietary nutrients or energy, and to identify major causes of emission variations. The review focused on $\mathrm{NH}_{3}$ emissions from beef feedlots and dairy cattle barns, and enteric $\mathrm{CH}_{4}$ emissions from cattle. $\mathrm{NH}_{3}$ and $\mathrm{CH}_{4}$ emissions from lagoons or other manure storage facilities were not included in this review.

\section{Literature Search and Data Analysis}

An exhaustive search using multiple strategies was undertaken to identify eligible studies to be included in the review. The literature searches were performed in the following electronic bibliographic databases: AGRICOLA, AGRIS, Biological \& Agricultural Index, Biological Abstracts, CAB Abstracts, CAB Reviews, Environment Complete, Pollution Abstracts, Web of Science, and Google Scholar. In each database, an iterative process was used to refine the search strategy through testing of several search terms and incorporation of new search terms as new relevant studies were identified. A manual search was carried out for references that were cited in the identified studies. The inclusion criteria were that the study must report measured $\mathrm{NH}_{3}$ or enteric $\mathrm{CH}_{4}$ emission from cattle operations and the emission can be expressed as a percentage of intakes of dietary nutrients or energy based on given information. The study must be published in English and inclusion was not restricted by study 
size or publication type. Studies that only reported emissions from manure storage facilities were not included.

Two individuals independently conducted the search processes and screened the studies by reading the title and abstract in order to select studies for full review according to the inclusion criteria. The included studies were distributed to a group of reviewers for data extraction. Standard data extraction sheets were developed for consistency. Each study was reviewed in duplicate by two independent reviewers for quality control. As a result of the data review and extraction processes, a database that included treatment means at various common feed and animal combinations from various studies was created and is available for independent scrutiny of the process.

For each study, the following general information was recorded: (1) Geographic region: Asia, Europe, North America, Oceania, or South America; (2) Cattle type: beef or dairy; (3) Average weight of animal, kg; (4) Number of animals measured; and (5) Measurement method.

For studies that reported $\mathrm{NH}_{3}$ emissions, the following variables were recorded in addition: (1) Farm type: beef feedlot, dairy open-lot, free-stall or tie-stall dairy barns; (2) Dietary crude protein (CP), \%; (3) N intake: g/day/animal; (4) Air temperature: outdoor air temperature for beef feedlots or dairy open-lots, indoor air temperature for free-stall/tie-stall dairy barns, ${ }^{\circ} \mathrm{C} ;(5)$ Ventilation: natural or mechanical; (6) Floor type: solid or slatted; (7) $\mathrm{NH}_{3}$ emission per animal, g/day/animal; and (8) $\mathrm{NH}_{3}-\mathrm{N}$ loss as a percentage of $\mathrm{N}$ intake.

For studies that reported $\mathrm{CH}_{4}$ emissions, the following variables were recorded in addition: (1) Breed of animal; (2) Lactation status: lactating or dry; (3) Days in milk: for lactating dairy; (4) Feeding method: grazing or housed; (5) Diet forage-to-concentrate ratio; (6) Fat content in diet, g/kg DM; (7) Energy digestibility of feed (ED), \%; (8) General energy intake (GEI), MJ/day/animal; (9) Energy intake level (EIL): calculated as ratio of digestible energy intake to energy requirement for maintenance of cattle; (10) $\mathrm{CH}_{4}$ emission per head, g/day/animal; (11) $\mathrm{Y}_{\mathrm{m}}$ : percentage of GEI converted to $\mathrm{CH}_{4}$; and (12) $\mathrm{D}$ : percentage of digestible energy intake converted to $\mathrm{CH}_{4}$.

When a study provided treatment means at different conditions (sites), multiple treatment means (data points) were extracted from the study. Treatment means from special feed additive experiments were considered not representative and thus were not included.

Normality of the data across studies was evaluated using the Shapiro-Wilk test, and funnel plots were used to detect potential publication bias, using number of animals measured as the $y$-axis. The MIXED procedures of SAS (SAS for Windows, ver. 9.4, SAS Institute, Cary, NC, USA) were used to investigate effects of various factors. The study effect was treated as a random variable since some studies contain multiple data points. The number of animals contributing to each treatment mean was used as a weighting variable. A backward elimination process was used to remove the confounded terms and to reduce non-significant terms one by one. The data were also classified into various homogeneous subgroups to conduct subgroup analysis based on identified significant factors such as farm type. In each subgroup, regressions were undertaken to quantify the effects of identified important variables, such as air temperature and dietary $\mathrm{CP}$ for $\mathrm{NH}_{3}$, and feed digestibility and energy intake for $\mathrm{CH}_{4}$. Significant effects were declared at $p$-value $<0.05$.

\section{3. $\mathrm{NH}_{3}$ Emissions as a Loss of Dietary Nutrients}

\subsection{Overall Statistics}

Under practical conditions, only $20 \%$ to $35 \%$ of the nitrogen $(\mathrm{N})$ fed to a dairy cow is secreted in milk [4,5]. For beef cattle, only $10 \%$ to $20 \%$ of the $\mathrm{N}$ consumed is retained by the animal [6]. Almost all of the remaining $\mathrm{N}$ is excreted in urine and feces. The $\mathrm{N}$ in the urine is mainly in the form of urea, which can rapidly be converted to $\mathrm{NH}_{3}$ when in contact with the urease enzyme in feces. It has been reported that $\mathrm{NH}_{3}$ emissions from cattle operations could be linearly related with feed $\mathrm{N}$ intake [7] and are sensitive to $\mathrm{CP}$ in rations [8]. However, in reality, the total $\mathrm{N}$ volatilization from manure (primarily 
in the form of $\mathrm{NH}_{3}$ ) had wide variations, ranging from $5 \%$ to $80 \%$ of manure $\mathrm{N}$, depending on the type of manure management system [9].

The literature search yielded a total of 92 papers published from 1997 to 2016, which included 173 treatment means of measured $\mathrm{NH}_{3}-\mathrm{N}$ loss as a percentage of $\mathrm{N}$ intake at various animal and farm type combinations for beef or dairy cattle operations. Distributions of these treatment means are presented in Figure 2. The average $\mathrm{NH}_{3}-\mathrm{N}$ loss as a percentage of $\mathrm{N}$ intake were $53.1 \%, 15.6 \%, 8.4 \%$, and 5.6\% for beef feedlots, dairy open-lots, free/tie-stall dairy barns with natural ventilation, and free/tie-stall dairy barns with mechanical ventilation, respectively. Although the average emission rates for dairy open-lots (125.6 g/day/animal) were comparable with that for beef feedlots (105.9 g/day/animal), the average $\mathrm{NH}_{3}-\mathrm{N}$ loss as a percentage of $\mathrm{N}$ intake for dairy open-lots was less than one third of that for beef feedlots $(15.6 \%$ vs. $53.1 \%)$ because dairy cattle usually have much higher $\mathrm{N}$ intake. The $\mathrm{NH}_{3}-\mathrm{N}$ loss as a percentage of $\mathrm{N}$ intake for dairy open-lots was about two times higher than that for free/tie-stall dairy barns with natural or mechanical ventilation when emissions from manure storage facilities were not included $(15.6 \%$ vs. $8.4 \%$ or $5.6 \%)$. The total $\mathrm{NH}_{3}-\mathrm{N}$ loss as a percentage of $\mathrm{N}$ intake that for dairy barns with emissions from manure storage facilities included has been estimated to be $20 \%$ to $55 \%$ by the MidWest Plan Service [10], which was even larger than that for dairy open-lots $(15.6 \%)$. The average $\mathrm{NH}_{3}-\mathrm{N}$ loss as a percentage of $\mathrm{N}$ intake for dairy barns with mechanical ventilation was lower than that for dairy barns with natural ventilation. $\mathrm{Th} \mathrm{NH}_{3}-\mathrm{N}$ loss as a percentage of $\mathrm{N}$ intake for beef feedlots and dairy open-lots both demonstrated a normal distribution. In contrast, the $\mathrm{NH}_{3}-\mathrm{N}$ loss as a percentage of $\mathrm{N}$ intake for free/tie-stall dairy barns with natural or mechanical ventilation demonstrated a skewed distribution with a long tail on the right side, which indicated the heterogeneity caused by relatively complex influencing factors in free/tie-stall barns, such as various manure handling practices, ventilation and floor types. No evidence of publication bias was found based on the funnel plots.
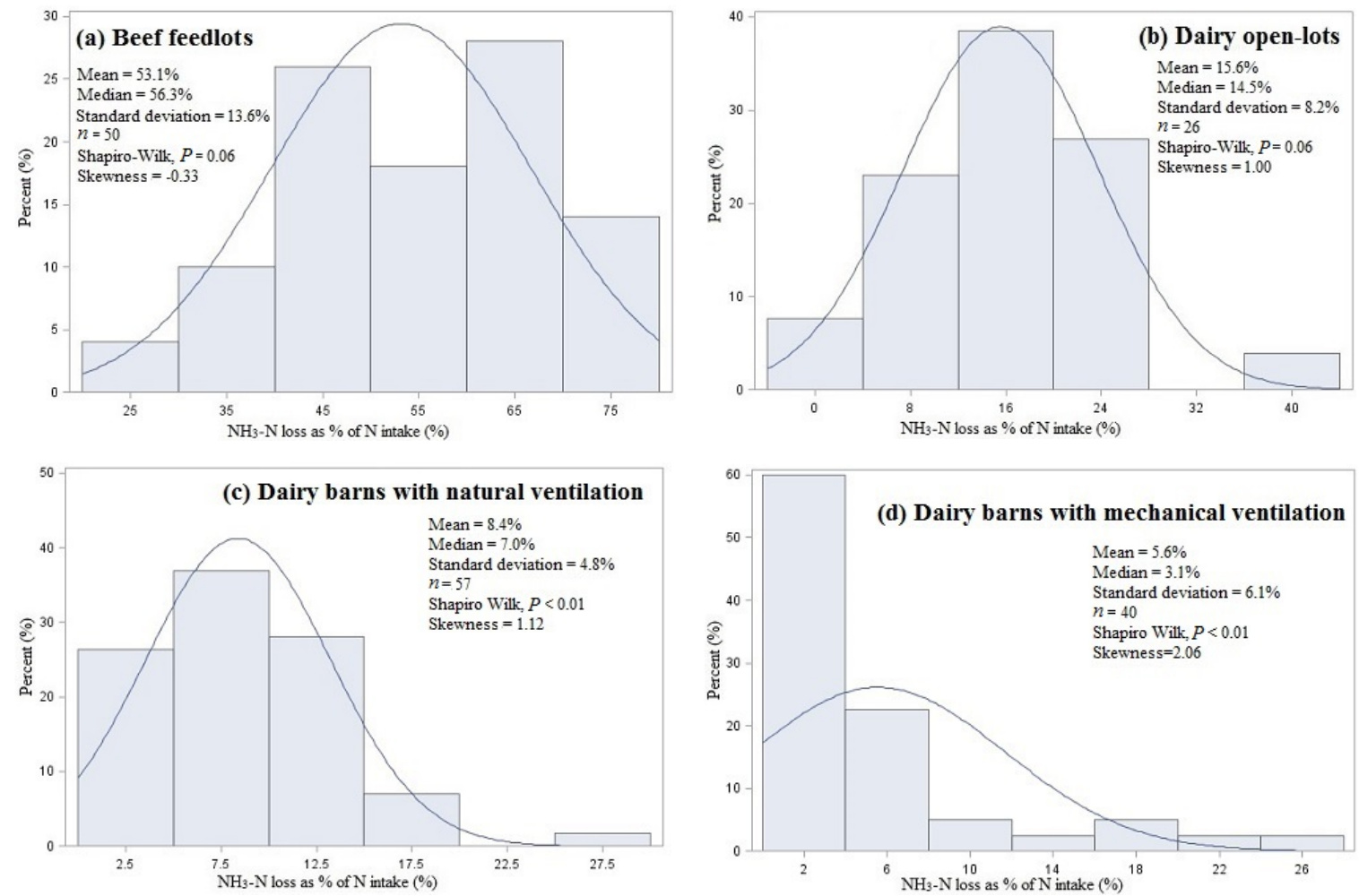

Figure 2. Histograms of $\mathrm{NH}_{3}-\mathrm{N}$ loss as a percentage of $\mathrm{N}$ intake for: (a) beef feedlots; (b) dairy open-lots; (c) dairy barns with natural ventilation; and (d) dairy barns with mechanical ventilation. 


\subsection{Effect of Air Temperature}

Air temperature can significantly affect $\mathrm{NH}_{3}$ emissions due to its effect on $\mathrm{NH}_{3}$ volatilization and convective mass transfer [11]. Todd [12] reported that summer emissions from a cattle feedyard were about twice as great as in the winter. Regressions were conducted for $\mathrm{NH}_{3}-\mathrm{N}$ loss as \% of $\mathrm{N}$ intake as a function of air temperature using data from the literature, and fit plots are presented in Figure 3. For beef feedlot, dairy open-lots, and dairy barns with natural ventilation, the $\mathrm{NH}_{3}-\mathrm{N}$ loss as $\%$ of $\mathrm{N}$ intake all increased with increasing temperature. However, for dairy barns with mechanical ventilation, the effect of air temperature was not significant $(p=0.48, n=32)$. This was likely due to the large variation of emissions dominated by various mechanical ventilation conditions, since the mechanical ventilation system design determines air velocity near the floor, and thus has significant influence on $\mathrm{NH}_{3}$ emission in dairy barns [11]. The sensitivity of $\mathrm{NH}_{3}-\mathrm{N}$ loss as a percentage of $\mathrm{N}$ intake to temperatures obtained from studies on dairy barns with natural ventilation was comparable with that for open-lot dairy barns $\left(0.46 \%\right.$ vs. $0.40 \%$ per $\left.{ }^{\circ} \mathrm{C}\right)$, while the sensitivity was higher for beef feedlots $\left(0.72 \%\right.$ per $\left.{ }^{\circ} \mathrm{C}\right)$. This was because beef cattle usually have lower $\mathrm{N}$ intake than dairy cattle. In fact, the sensitivity of $\mathrm{NH}_{3}$ emission rate in $\mathrm{g} / \mathrm{d}$ /animal to air temperature obtained from various types of cattle operations was comparable with each other $\left(2.33,2.39,2.66 \mathrm{~g} /\right.$ day / animal per ${ }^{\circ} \mathrm{C}$, respectively, for beef feedlots, dairy open-lots, and dairy barns with natural ventilation).
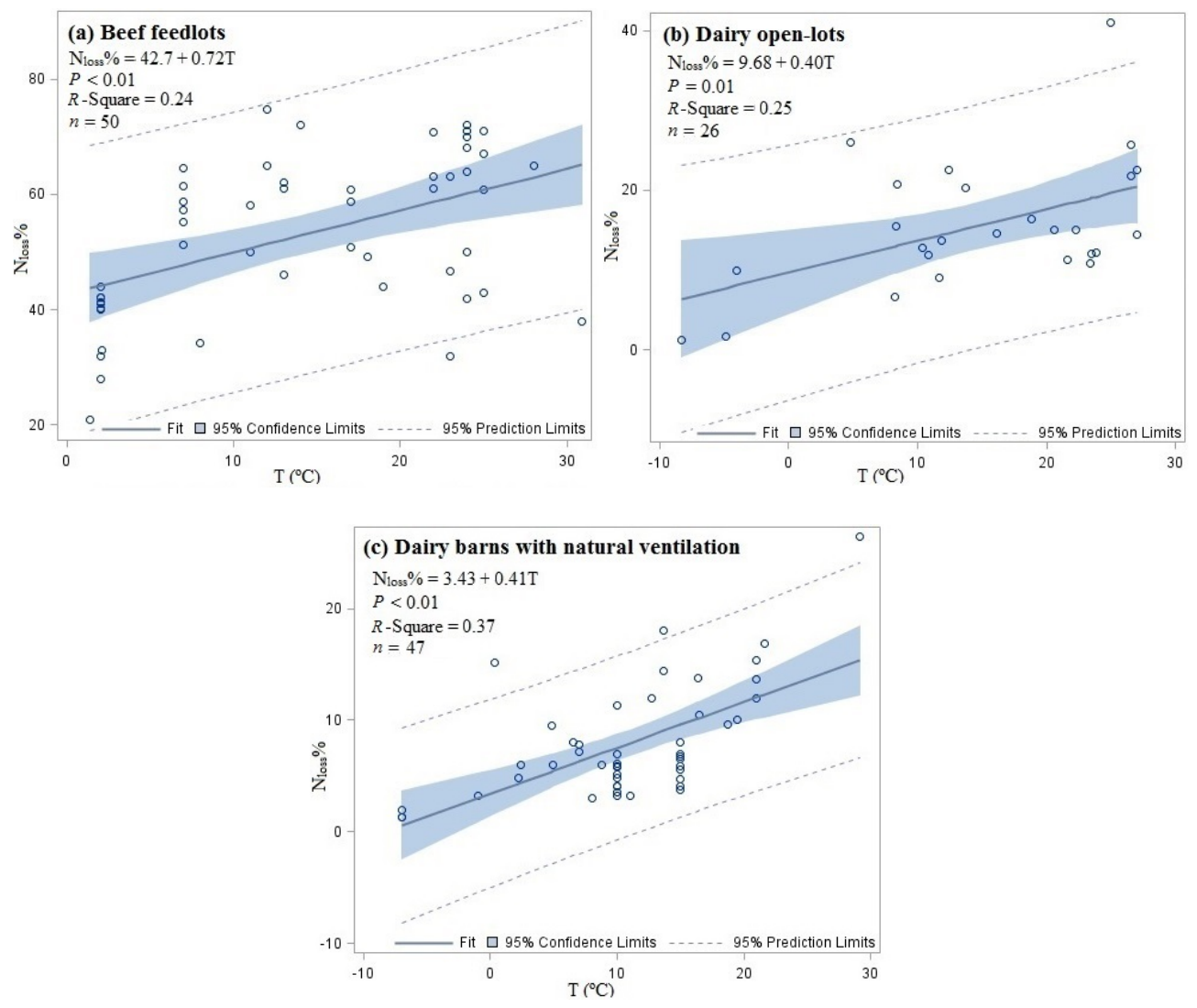

Figure 3. Fit plots for $\mathrm{NH}_{3}-\mathrm{N}$ loss as a percentage of $\mathrm{N}$ intake $\left(\mathrm{N}_{\text {loss }} \%\right)$ as a function of air temperature (T) for: (a) beef feedlots; (b) dairy open-lots; and (c) dairy barns with natural ventilation.

\subsection{Effect of Dietary Crude Protein (CP) Content}

Another important factor that affects $\mathrm{NH}_{3}$ emissions is dietary $\mathrm{CP}$. For beef feedlots, open-lot dairy barns and dairy barns with natural ventilation, the $\mathrm{NH}_{3}$ emission rates were significantly affected by both air temperature and dietary $\mathrm{CP}(p<0.05)$. When both air temperature and dietary $\mathrm{CP}$ were included in regression, the sensitivity of emission rates to dietary $\mathrm{CP}$ obtained for various types of cattle 
operations was 9.9, 12.7, and $10.4 \mathrm{~g} \cdot \mathrm{day}^{-1} \cdot \mathrm{animal}^{-1}$ per $1 \% \mathrm{CP}$, respectively, for beef feedlots, dairy open-lots and free/tie-stall dairy barns with natural ventilation. The result indicated that, for every one percentage point increase in dietary CP (e.g., from $14 \%$ to $15 \%$ ), an increase of 9.9 to $12.7 \mathrm{~g} /$ day /animal in $\mathrm{NH}_{3}$ emission rates can be expected. This was comparable with the results of Bougouin et al. [13], which concluded that a unit increase in dietary $\mathrm{CP}$ resulted in a $10.2 \mathrm{~g} /$ day/animal increase in $\mathrm{NH}_{3}$ emissions from dairy operations. The effect of dietary $\mathrm{CP}$ on $\mathrm{NH}_{3}$ emissions for free/tie-stall dairy barns with mechanical ventilation was not observed, possibly due to the large variation in emissions dominated by mechanical ventilation conditions. For beef feedlots and dairy barns with natural ventilation, higher dietary $\mathrm{CP}$ not only resulted in higher $\mathrm{NH}_{3}$ emission rates but also corresponded with higher $\mathrm{NH}_{3}-\mathrm{N}$ loss as percentage of $\mathrm{N}$ intake, although the effect was not statistically significant at $\alpha=0.05$ level ( $p=0.31$ and 0.14 , respectively, for beef feedlots and dairy barns with natural ventilation). Figure 4 demonstrates the effect of dietary $\mathrm{CP}$ on $\mathrm{NH}_{3}$ emission rate as well as on the $\mathrm{NH}_{3}-\mathrm{N}$ loss as percentage of $\mathrm{N}$ intake for beef feedlots when dietary $\mathrm{CP}$ was the only factor considered in the regression. The results were in agreement with the report that the proportion of total $\mathrm{N}$ excreted in urine was positively related with dietary CP [14]. Huhtanen et al. [15] once estimated that $84 \%$ of the incremental $\mathrm{N}$ intake was excreted in urine. The excess $\mathrm{CP}$ fed to the animal is mostly voided as urea in urine, and thus will result in increased percentage of $\mathrm{N}$ excreted in urine and increased percentage of $\mathrm{N}$ loss as $\mathrm{NH}_{3}$. The effect of dietary $\mathrm{CP}$ on $\mathrm{NH}_{3}-\mathrm{N}$ loss as a percentage of $\mathrm{N}$ intake for dairy open-lots was not observed, possibly due to the limited number of data points in literature. More studies on dairy open-lots using various dietary $\mathrm{CP}$ levels are needed to better evaluate the effect of dietary $\mathrm{CP}$.
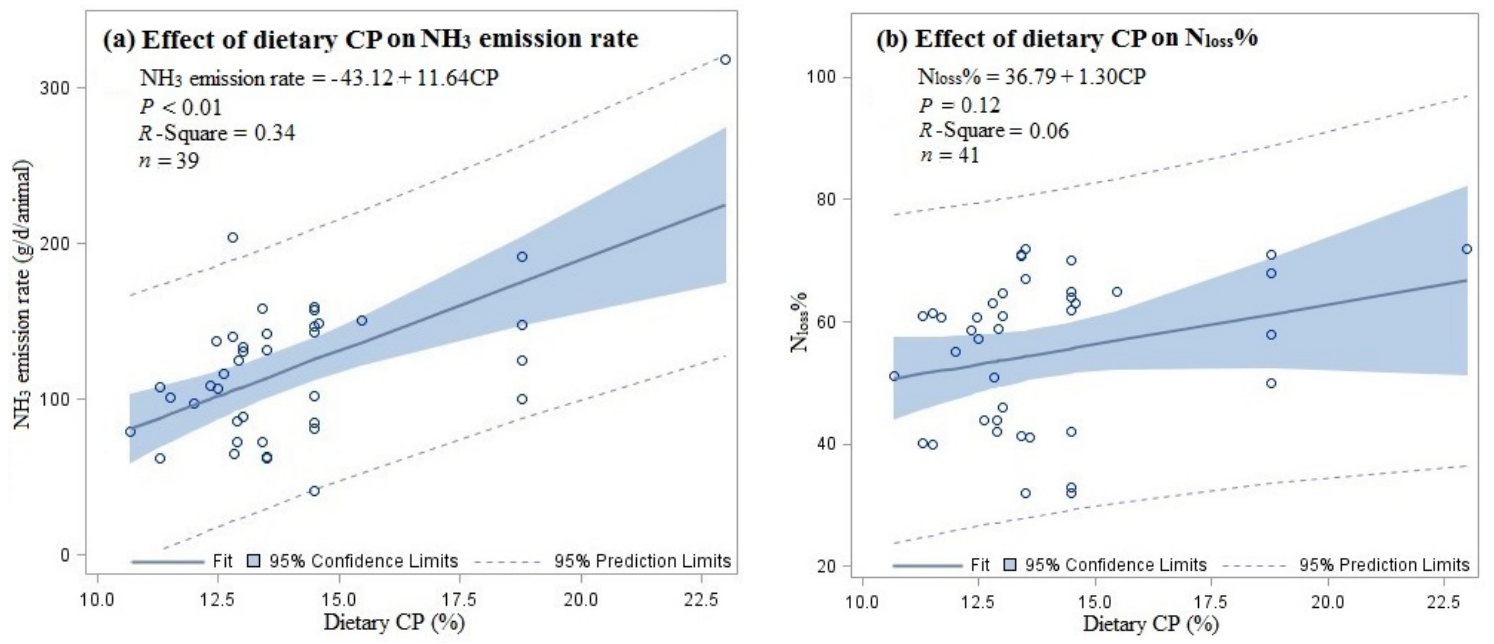

Figure 4. Fit plots for (a) $\mathrm{NH}_{3}$ emission rate and (b) $\mathrm{NH}_{3}-\mathrm{N}$ loss as a percentage of $\mathrm{N}$ intake $\left(\mathrm{N}_{\text {loss }} \%\right)$ as a function of dietary crude protein $(\mathrm{CP})$ for beef feedlots.

\subsection{Other Factors That Affect $\mathrm{NH}_{3}$ Emission}

There are many other factors that can affect $\mathrm{NH}_{3}$ emissions from cattle operations, such as manure handling practices (scraping or flushing), manure removal frequency, floor types (solid or slatted), barn types (free-stall or tie-stall), ventilation of barns, wind speed/solar radiation/precipitation for open-lots, etc. It is very difficult to quantify and generalize the effects of these factors with the limited amount of data in literature, and many of these factors were confounded with each other. As mentioned earlier, the $\mathrm{NH}_{3}-\mathrm{N}$ loss as a percentage of $\mathrm{N}$ intake for dairy barns with mechanical ventilation was lower than that for dairy barns with natural ventilation. The effect of ventilation type was confounded by barn type. One possible reason for lower emissions from barns with mechanical ventilation is that $72 \%$ of the barns with mechanical ventilation were tie-stall barns, while $96 \%$ of the barns with natural ventilation were free-stall barns in the data analyzed. The beddings typically used in tie-stall barns can separate urine and feces and thus reduce $\mathrm{NH}_{3}$ production [16], and the emitting surface area of 
tie-stall barns was often less than that of free-stall barns [17]. Another reason could be that mechanical ventilation can reduce moisture in barns and thus reduce $\mathrm{NH}_{3}$ emissions. Generally, the $\mathrm{NH}_{3}-\mathrm{N}$ loss as a percentage of $\mathrm{N}$ intake for free/tie-stall dairy barns demonstrated much larger variation than that for beef feedlots. The coefficients of variation were $0.3,0.5,0.6$, and 1.1 for beef feedlots, dairy open-lots, free/tie-stall dairy barns with natural ventilation, and free/tie-stall dairy barns with mechanical ventilation. The larger variation and the skewed distribution with long tails on the right side in Figure 2c, d indicated that there may be considerable room for reducing $\mathrm{NH}_{3}$ emission with improved management practices in free/tie-stall dairy barns, especially in barns with mechanical ventilation. When developing mitigating strategies, for open-lot dairy barns and beef feedlots, managing $\mathrm{N}$ intake and improving feed efficiency seem to represent the greatest opportunities. For free/tie-stall dairy barns, improving ventilation design and management practices could be more effective.

\section{Enteric $\mathrm{CH}_{4}$ Emissions as a Loss of Dietary Energy}

\subsection{Overall Statistics}

Since $\mathrm{CH}_{4}$ represents an unproductive loss of dietary energy, one of the predominant enteric $\mathrm{CH}_{4}$ emission estimation procedures is driven by first estimating daily gross energy intake (GEI) by individual animals and then multiplying the GEI by an estimate of "methane conversion factor $\left(\mathrm{Y}_{\mathrm{m}}\right)^{\prime \prime}$, which ranges from $2 \%$ to $11 \%$ of GEI in literature. An alternative approach is to express $\mathrm{CH}_{4}$ conversion factors on a digestible energy basis. $\mathrm{D}_{\mathrm{m}}$ was defined as percentage of digestible energy intake converted to $\mathrm{CH}_{4}$. Typical ruminant diets contain about $18.4 \mathrm{MJ}$ of gross energy (GE) per $\mathrm{kg}$ of dry matter (DM) and $\mathrm{CH}_{4}$ has energy content of $55.65 \mathrm{MJ} / \mathrm{kg}$ [18]. Therefore, a typical $\mathrm{Y}_{\mathrm{m}}$ value of $6 \%$ corresponds to $19.8 \mathrm{~g} \mathrm{CH}_{4} / \mathrm{kg} \mathrm{DM}$ intake. Assuming the energy digestibility of feed is $65 \%$, a $\mathrm{Y}_{\mathrm{m}}$ value of $6.5 \%$ corresponds to a $D_{m}$ value of $10 \%$.

The literature search yielded a total of 89 papers published from 1992 to 2015, which included 217 treatment means of measured enteric $\mathrm{CH}_{4}$ loss as a percentage of dietary energy intake at various animal and farm type combinations for beef or dairy cattle operations. The treatment means of $Y_{m}$ or $\mathrm{D}_{\mathrm{m}}$ were obtained from these studies directly or calculated based on given information. Distributions of these treatment means are presented in Figure 5. No significant difference was observed between beef and dairy cattle for $Y_{m}(p=0.79)$ or $\mathrm{D}_{\mathrm{m}}(p=0.93)$. Grazing cattle had higher $\mathrm{Y}_{\mathrm{m}}$ than housed cattle $(7.3 \%$ vs. $6.1 \%, p<0.01)$, but $\mathrm{D}_{\mathrm{m}}$ was not significantly affected by feeding method $(p=0.56)$. The difference in $Y_{m}$ between grazing and housed cattle could be due to the effect of feed digestibility. No evidence of publication bias was found based on the funnel plot.
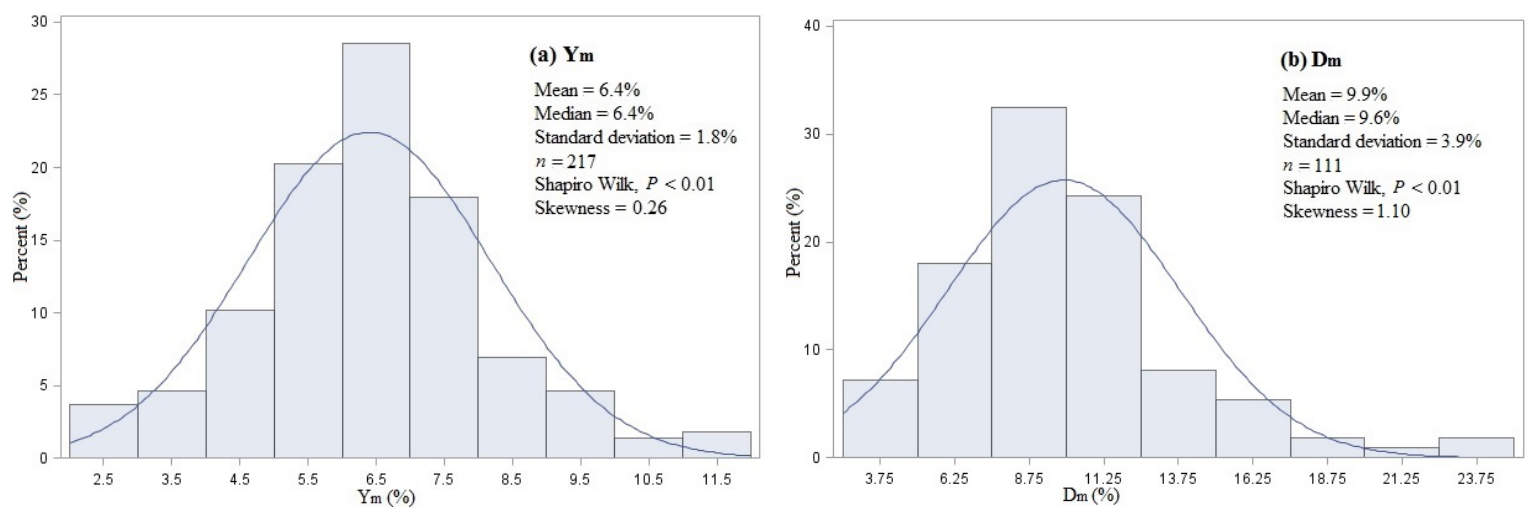

Figure 5. Histograms of $\mathrm{CH}_{4}$ conversion factors on gross energy intake (GEI) or digestible energy basis: (a) $\mathrm{Y}_{\mathrm{m}}: \mathrm{CH}_{4}$ loss as a percentage of GEI; and (b) $\mathrm{D}_{\mathrm{m}}: \mathrm{CH}_{4}$ loss as a percentage of digestible energy intake. 


\subsection{Effect of Feed Digestibility}

Increasing the proportion of concentrate in the diet will likely increase animal productivity and thus decrease enteric $\mathrm{CH}_{4}$ emission per unit of animal product even though the absolute $\mathrm{CH}_{4}$ emissions may not be reduced [19-21]. The default values of $Y_{m}$ provided by the Intergovernmental Panel on Climate Change (IPCC) [9] are 3.0\% $\pm 1.0 \%$ for feedlot cattle that are fed diets containing $90 \%$ or more concentrates, and $6.5 \% \pm 1.0 \%$ for dairy cows and cattle that are primarily fed low quality crop residues and by-products. Analysis of data across studies showed that lower forage-to-concentrate ratio in diets generally resulted in lower $Y_{m}$ and $D_{m}\left(p<0.01\right.$ for both $Y_{m}$ and $\left.D_{m}\right)$. The least squares mean of $Y_{m}$ for cattle that were fed diets containing $90 \%$ or more concentrates was $3.8 \% \pm 0.5 \%$, which was higher than the $3.0 \% \pm 1.0 \%$ provided by the IPCC [9]. In contrast, the least squares mean of $\mathrm{Y}_{\mathrm{m}}$ for cattle that were fed diets containing $10 \%$ or less concentrates was $7.3 \% \pm 0.4 \%$. Lower forage-to-concentrate ratio in diets corresponded to higher digestibility. Typical feed energy digestibility in U.S. was $66.7 \%$ for dairy cows and $82.5 \%$ for feedlot cattle in 2012 [2]. For grazing cattle, forage digestibility is mainly affected by stage of maturity and forage species in addition to environmental conditions [22,23]. Increased forage digestibility is expected to decrease enteric $\mathrm{CH}_{4}$ emission per unit of animal products [21]. Based on the 51 studies included in this review, the average feed energy digestibility for grazing cattle was $58.8 \%, 68.0 \%$, and $70.2 \%$ in North America, Europe, and Oceania, respectively, which provided an explanation for the higher $Y_{m}$ in North America as compared with Europe and Oceania (7.7\% vs. $6.6 \%$ and $5.7 \%)$. The observed higher $Y_{m}$ for grazing cattle as compared with housed cattle was expected since grazing cattle generally had lower feed digestibility than most housed cattle. Regressions were conducted for $\mathrm{Y}_{\mathrm{m}}$ and $\mathrm{D}_{\mathrm{m}}$ as a function of feed energy digestibility using data from literature including both housed and grazing cattle studies, and fit plots are presented in Figure 6 . As shown in Figure 6, $D_{m}$ demonstrated a much better fit than $Y_{m}$ to reflect the effect of feed energy digestibility on $\mathrm{CH}_{4}$ emissions.
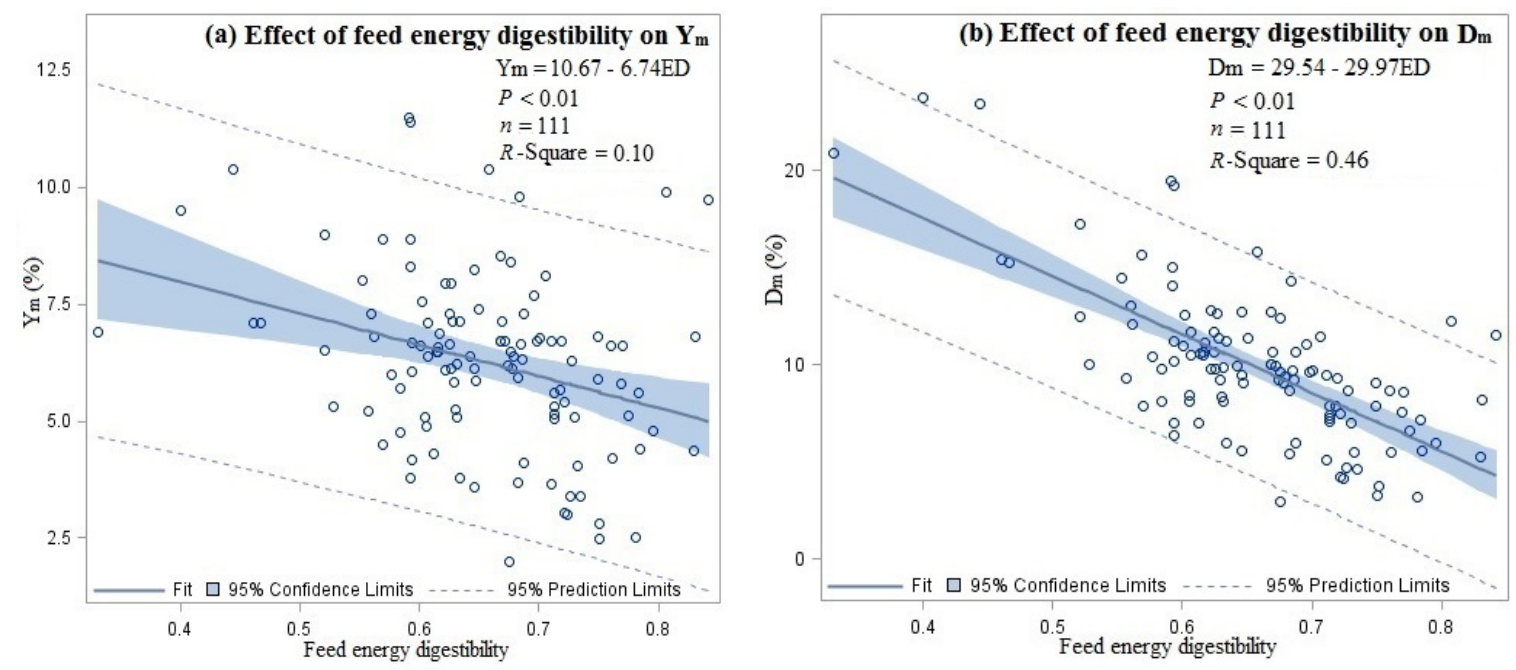

Figure 6. Fit plots for (a) $\mathrm{Y}_{\mathrm{m}}\left(\mathrm{CH}_{4}\right.$ loss as a percentage of GEI) and (b) $\mathrm{D}_{\mathrm{m}}\left(\mathrm{CH}_{4}\right.$ loss as a percentage of digestible energy intake) as a function of feed energy digestibility.

\subsection{Effect of Energy Intake}

Enteric fermentation and hence $Y_{m}$ was also affected by feed intake. Kujawa [24] and Diarra [25] reported that $Y_{m}$ varied from $8 \%$ to $11 \%$ when measured at restricted feed intakes and from $5 \%$ to $6 \%$ when measured at ad libitum intake. Johnson and Johnson [26] stated that as feed intake increased, the $Y_{m}$ decreased by about 1.6 percent-units per each level of intake above maintenance. Sauvant and Giger-Reverdin [27] reported a linear decrease in $Y_{m}$ with increasing feed intake. Feed digestibility and intake level could affect each other. Increasing feed digestibility could help to increase intake level, 
and, conversely, excessive intake could reduce digestibility [27-29]. Generally, high digestibility did not necessarily result in a high intake level, but low digestibility usually resulted in a low intake level. However, a strong relationship between them has not been documented [26].

In this review, the energy intake level (EIL) was defined as the ratio of digestible energy intake to energy requirement for maintenance of cattle and was used to evaluate the effect of feed intake. It was calculated for all reviewed studies when needed information was available. The energy requirement for maintenance $\left(\mathrm{NE}_{\mathrm{m}}\right)$ was estimated using an equation from the IPCC [9]:

$$
\mathrm{NE}_{\mathrm{m}}=\mathrm{Cf}_{\mathrm{i}} \times(\text { Weight })^{0.75},
$$

in which $\mathrm{Cf}_{\mathrm{i}}$ is a coefficient that varies for each animal category. Assuming the efficiency of conversion of digestible energy to metabolisable energy (ME) is 0.82 and the efficiency of conversion of ME to $\mathrm{NE}_{\mathrm{m}}$ ranges from 0.64 to 0.70 [30], when the $\mathrm{ME}$ available in feed intake equals the ME required for maintenance, the corresponding EIL is around 1.74 to 1.90. Both $Y_{m}$ and $D_{m}$ decreased with increasing EIL $\left(p<0.01\right.$ for both $\mathrm{Y}_{\mathrm{m}}$ and $\left.\mathrm{D}_{\mathrm{m}}\right)$ as expected when EIL was the only factor considered in the regression (Figure 7).
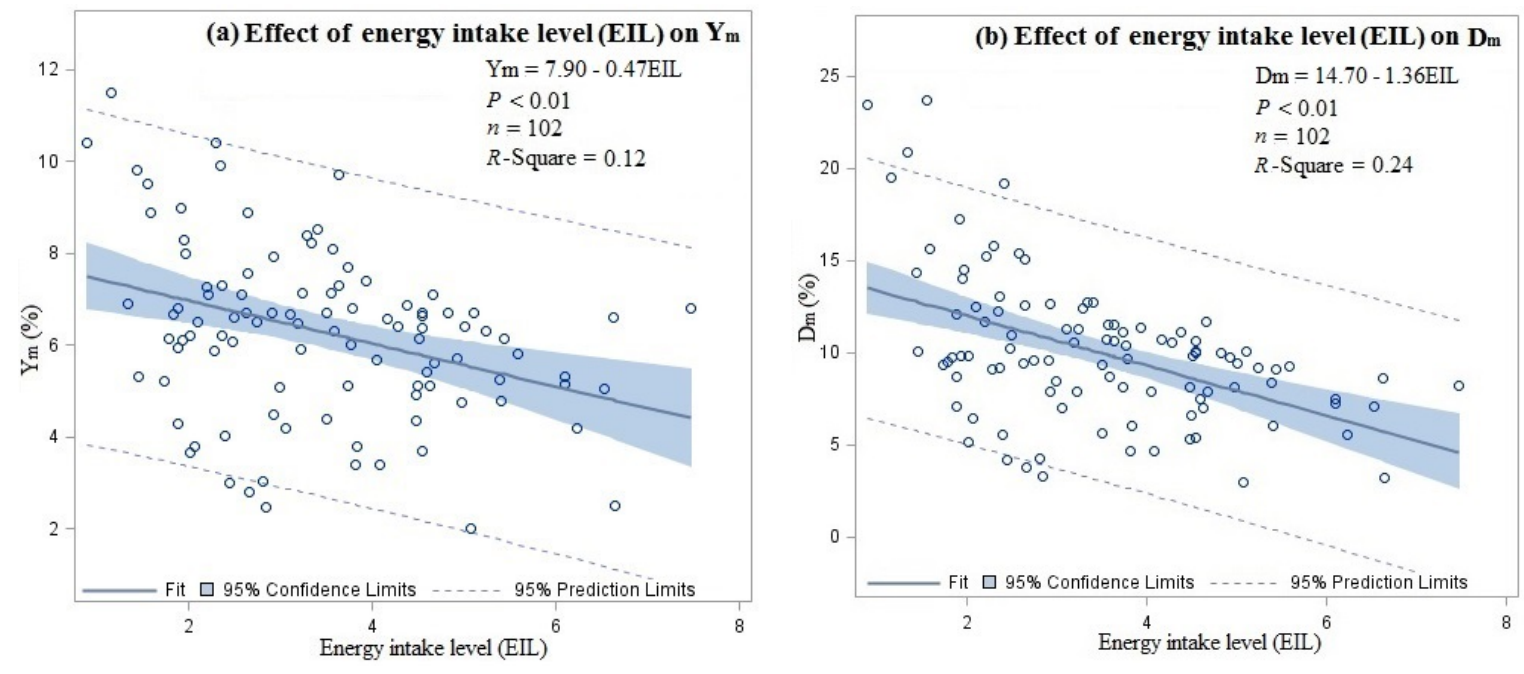

Figure 7. Fit plots for (a) $\mathrm{Y}_{\mathrm{m}}\left(\mathrm{CH}_{4}\right.$ loss as a percentage of GEI) and (b) $\mathrm{D}_{\mathrm{m}}\left(\mathrm{CH}_{4}\right.$ loss as a percentage of digestible energy intake) as a function of energy intake level (EIL).

When effects of EIL and energy digestibility of feed were both included in a two-factor analysis, increasing EIL reduced $\mathrm{Y}_{\mathrm{m}}(p=0.02)$, but the effect of feed energy digestibility was no longer significant $(p=0.07)$. A significant effect of digestibility on $\mathrm{CH}_{4}$ emission could not be demonstrated possibly due to the limitations of the $Y_{m}$ approach. The limitations of the $Y_{m}$ approach have been noted [21,31,32]. Boadi and Wittenberg [31] fed low, medium and high quality forage to dairy and beef cattle and reported no statistical differences in $Y_{m}$, but greater emissions with the lower quality forages were observed when expressed on digestible energy intake basis. Based on this review, $D_{m}$ was significantly affected by both EIL and feed energy digestibility in a two-factor analysis ( $p<0.01$ for both effects). An interaction effect was also observed $(p<0.01)$. The following regression model (Equation (2)) was developed based on data from all studies that provided $D_{m}$, energy digestibility and EIL ( $n=100$, $R$-Square $=0.54$ ). Based on the regression model, the sensitivity of $D_{m}$ to feed energy digestibility decreased as EIL increased. On the other hand, the sensitivity of $D_{m}$ to EIL decreased as feed energy digestibility increased:

$$
\mathrm{D}_{\mathrm{m}}=40.69-43.84 \times \mathrm{ED}-4.870 \times \mathrm{EIL}+6.368 \times \mathrm{ED} \times \mathrm{EIL},
$$


where ED is feed energy digestibility, ranging from 0.33 to 0.84 ; EIL is energy intake level of cattle, measured as the ratio of digestible energy intake to the energy requirement for maintenance of cattle, ranging from 0.89 to 7.47 ; and $\mathrm{D}_{\mathrm{m}}$ is percentage of digestible energy intake converted to $\mathrm{CH}_{4}$.

\subsection{Other Factors That Affect $\mathrm{CH}_{4}$ Emission}

Breed of cattle could be another factor that can affect enteric $\mathrm{CH}_{4}$ emissions. The least squares mean of $Y_{m}$ for Holstein cattle is $5.3 \%(n=52)$. The limited data in literature showed that Thai native, Brown Swiss and Brahman cattle reported higher $Y_{m}$ than Holstein cattle, while Nellore cattle reported lower $Y_{m}$ than Holstein cattle. Fat supplementation has been proposed to reduce $\mathrm{CH}_{4}$ emission [33,34], but the microbiological mechanism was not well known. Increasing fat content may decrease digestibility [35] and increase energy intake level. The effect of fat content in diets on $\mathrm{CH}_{4}$ emission could be related to its effects on feed digestibility and energy intake level of cattle. The lactation status of dairy cows could also affect $\mathrm{CH}_{4}$ emission indirectly by affecting energy intake level, since, generally, energy intake level of lactating cows is higher than that of dry cows, and it decreases with increasing days in milk. For grazing cattle, geographic region can affect $\mathrm{CH}_{4}$ emission indirectly by affecting feed digestibility. As mentioned before, North America reported lower digestibility and thus higher $Y_{m}$ as compared with Europe and Oceania.

\section{Conclusions}

The $\mathrm{NH}_{3}$ and $\mathrm{CH}_{4}$ emission expressed as percentage losses of dietary nutrients or energy both demonstrated much less variation compared with emission rates expressed in $\mathrm{g} / \mathrm{animal} /$ day. In reality, protein is often fed to livestock above the requirements for growth and maintenance. Improving nutrient management at the farm level and reducing protein intake have been considered as relatively easy ways of reducing $\mathrm{NH}_{3}$ emissions from cattle operations [36]. The $\mathrm{NH}_{3}-\mathrm{N}$ loss as a percentage of $\mathrm{N}$ intake was significantly different for various types of farms. Air temperature and dietary $\mathrm{CP}$ content were identified as two major factors that can affect $\mathrm{NH}_{3}$ emission in addition to farm type. In developing $\mathrm{NH}_{3}$ mitigation strategies, generally, managing $\mathrm{N}$ intake and improving feed efficiency seem to represent the greatest opportunities. In contrast, the larger variation and the skewed distribution of data in the literature indicated that there may be considerable room for reducing existing $\mathrm{NH}_{3}$ emission with improved management practices in free/tie-stall dairy barns, especially in barns with mechanical ventilation. Feed digestibility and energy intake were identified as two major factors that can affect $\mathrm{CH}_{4}$ emission expressed as percentage losses of dietary energy. Generally, higher energy digestibility of feed and higher energy intake level of cattle resulted in lower percentage of digestible energy intake converted to $\mathrm{CH}_{4}$. Increasing productivity and feed efficiency represent the greatest opportunity for mitigating $\mathrm{CH}_{4}$ emissions per unit of livestock product. However, expressing enteric $\mathrm{CH}_{4}$ energy production on GEI does not have the capacity to fully reflect the effects of diet quality and composition. Compared with the $\mathrm{Y}_{\mathrm{m}}$ approach, the use of $\mathrm{CH}_{4}$ conversion factor on a digestible energy basis $\left(D_{m}\right)$ can better represent the large variation among diets and the effects of varying dietary emission mitigation strategies.

Acknowledgments: This study is contribution No. 17-223-J from the Kansas Agricultural Experiment Station. Publication of this article was funded in part by the Kansas State University Open Access Publishing Fund.

Author Contributions: Zifei Liu and Yang Liu processed and analyzed the data. Zifei Liu wrote the paper. James P. Murphy and Ronaldo Maghirang reviewed and edited the paper.

Conflicts of Interest: The authors declare no conflict of interest.

\section{References}

1. National Research Council (NRC) of the National Academies. Air Emissions from Animal Feeding Operations: Current Knowledge, Future Needs; National Academies Press: Washington, DC, USA, 2003. 
2. United States Environmental Protection Agency (USEPA). Inventory of US Greenhouse Gas Emissions and Sinks: 1990-2012. 2014. Available online: https://www3.epa.gov/climatechange/Downloads/ ghgemissions/US-GHG-Inventory-2014-Main-Text.pdf (accessed on 22 February 2017).

3. United States Environmental Protection Agency (USEPA). 2008 National Emissions Inventory, Version 3. Technical Support Document. 2013. Available online: https://www.epa.gov/sites/production/files/201507/documents/2008_neiv3_tsd_draft.pdf (accessed on 22 February 2017).

4. Jonker, J.S.; Kohn, R.A.; High, J. Dairy herd management practices that impact nitrogen utilization efficiency. J. Dairy Sci. 2002, 85, 1218-1226. [CrossRef]

5. Liu, Z.; Powers, W.; Oldick, B.; Davidson, J.; Meyer, D. Gas emissions from dairy cows fed typical diets of midwest, south, and west regions of the United States. J. Environ. Qual. 2012, 41, 1228-1237. [CrossRef] [PubMed]

6. Cole, N.A.; Todd, R.W. Nitrogen and phosphorus balance of beef cattle feedyards. In Proceedings of the Texas Animal Manure Management Issues Conference, Texas AgriLife Extension, Round Rock, TX, USA, 29 September 2009; pp. 17-24.

7. James, T.; Meyer, D.; Esparza, E.; Depeters, E.J.; Perez-Monti, H. Effects of dietary nitrogen manipulation on ammonia volatilization from manure from Holstein heifers. J. Dairy Sci. 1999, 82, 2430-2439. [CrossRef]

8. Todd, R.W.; Cole, N.A.; Rhoades, M.B.; Parker, D.B.; Casey, K.D. Daily, monthly, seasonal, and annual ammonia emissions from southern High Plains cattle feedyards. J. Environ. Qual. 2011, 40, 1090-1095. [CrossRef] [PubMed]

9. Intergovernmental Panel on Climate Change (IPCC). IPCC Guidelines for National Greenhouse Gas Inventories; Agricultural, Forestry and Other Land Use; Institute for Global Environmental Strategies (IGES): Hayama, Japan, 2006; Volume 4.

10. MidWest Plan Service (MWPS). Manure Storages; Manure management system series; MWPS-18, Section 2: Ames, IA, USA, 2001.

11. Rong, L.; Nielsen, P.V.; Zhang, G. Effects of airflow and liquid temperature on ammonia mass transfer above an emission surface: Experimental study on emission rate. Bioresour. Tech. 2009, 100, 4654-4661. [CrossRef] [PubMed]

12. Todd, R.W.; Cole, N.A.; Clark, R.N.; Flesch, T.K.; Harper, L.A.; Baek, B.H. Ammonia emissions from a beef cattle feedyard on the southern High Plains. Atmos. Environ. 2008, 42, 6797-6805. [CrossRef]

13. Bougouin, A.; Leytem, A.B.; Dijkstra, J.; Dungan, R.S.; Kebreab, E. Nutritional and environmental effects on ammonia emissions from dairy cattle housing: A meta-analysis. J. Environ. Qual. 2016, 45, 1123-1132. [CrossRef] [PubMed]

14. Waldrip, H.M.; Todd, R.W.; Cole, N.A. Prediction of nitrogen excretion by beef cattle: A meta-analysis. J. Anim. Sci. 2013, 91, 4290-4302. [CrossRef] [PubMed]

15. Huhtanen, P.; Nousiainen, J.I.; Rinne, M.; Kytola, K.; Khalili, H. Utilization and partition of dietary nitrogen in dairy cows fed grass silage-based diets. J. Dairy Sci. 2008, 91, 3589-3599. [CrossRef] [PubMed]

16. Misselbrook, T.H.; Powell, J.M. Influence of bedding material on ammonia emissions from cattle excreta. J. Dairy Sci. 2005, 88, 4304-4312. [CrossRef]

17. Monteny, G.J.; Erisman, J.W. Ammonia emission from dairy cow buildings: A review of measurement techniques, influencing factors, and possibilities for reduction. Neth. J. Agric. Sci. 1998, 46, 225-247.

18. Commonwealth Scientific and Industrial Research Organisation (CSIRO). Nutrient Requirements of Domesticated Ruminants; CSIRO Publishing: Melbourne, Australia, 2007.

19. McGeough, E.J.; O’Kiely, P.; Hart, K.J.; Moloney, A.P.; Boland, T.M.; Kenny, D.A. Methane emissions, feed intake, performance, digestibility and rumen fermentation of finishing beef cattle offered whole-crop wheat silages differing in grain content. J. Anim. Sci. 2010, 88, 2703-2716. [CrossRef] [PubMed]

20. Aguerre, M.J.; Wattiaux, M.A.; Powell, J.M.; Broderick, G.A.; Arndt, C. Effect of forage-to-concentrate ratio in dairy cow diets on emission of methane, carbon dioxide, and ammonia, lactation performance, and manure excretion. J. Dairy Sci. 2011, 94, 3081-3093. [CrossRef] [PubMed]

21. Hristov, A.N.; Oh, J.; Lee, C.; Meinen, R.; Montes, F.; Ott, T.; Firkins, J.; Rotz, A.; Dell, C.; Adesogan, A.; et al. Mitigation of Greenhouse Gas Emissions in Livestock Production-A Review of Technical Options for Non-CO $\mathrm{CO}_{2}$ Emissions; FAO Animal Production and Health Paper; Food and Agriculture Organization of the United Nations: Rome, Italy, 2013. 
22. West, J.W. Factors which Influence Forage Quality and Effectiveness in Dairy Rations. In Proceedings of the Western Canadian Dairy Seminar (USA); 1998. Available online: http://www.wcds.ca/proc/1998/ch13.htm (accessed on 22 February 2017).

23. Bruinenberg, M.H.; Valk, H.; Korevaar, H.; Struik, P.C. Factors affecting digestibility of temperate forages from seminatural grasslands: A review. Grass Forage Sci. 2002, 57, 292-301. [CrossRef]

24. Kujawa, M.A. Energy Partitioning in Steers Fed Cottonseed Hulls or Sugar Beet Pulp. Ph.D. Thesis, Colorado State University, Ann Arbor, MI, USA, 1994.

25. Diarra, B. Net Energy Value of Soybean Hulls as Feed for Sheep. Ph.D. Thesis, Colorado State University, Ann Arbor, MI, USA, 1994.

26. Johnson, K.A.; Johnson, D.E. Methane Emissions from Cattle. J. Anim. Sci. 1995, 73, 2483-2492. [CrossRef] [PubMed]

27. Sauvant, D.; Giger-Reverdin, S. Modelling of digestive interactions and methane production in ruminants. Prod. Anim. 2009, 22, 375-384.

28. National Research Council. Nutrient Requirements of Dairy Cattle, 7th ed.; National Academies Press: Washington, DC, USA, 2001.

29. Huhtanen, P.; Rinne, M.; Nousiainen, J. A meta-analysis of feed digestion in dairy cows. 2. The effects of feeding level and diet composition on digestibility. J. Dairy Sci. 2009, 92, 5031-5042. [CrossRef] [PubMed]

30. Agricultural Research Council (Great Britain). The Nutrient Requirements of Ruminant Livestock: Technical Review (No. 2); Commonwealth Agricultural Bureaux: Slough, UK, 1980.

31. Boadi, D.A.; Wittenberg, K.M. Methane production from dairy and beef heifers fed forages differing in nutrient density using the sulphur hexafluoride (SF6) tracer gas technique. Can. J. Anim. Sci. 2002, 82, 201-206. [CrossRef]

32. Kennedy, P.M.; Charmley, E. Methane yields from Brahman cattle fed tropical grasses and legumes. Anim. Prod. Sci. 2012, 52, 225-239. [CrossRef]

33. Grainger, C.; Williams, R.; Clarke, T.; Wright, A.D.G.; Eckard, R.J. Supplementation with whole cottonseed causes long-term reduction of methane emissions from lactating dairy cows offered a forage and cereal grain diet. J. Dairy Sci. 2010, 93, 2612-2619. [CrossRef] [PubMed]

34. Moate, P.J.; Williams, S.R.O.; Grainger, C.; Hannah, M.C.; Ponnampalam, E.N.; Eckard, R.J. Influence of cold-pressed canola, brewers grains and hominy meal as dietary supplements suitable for reducing enteric methane emissions from lactating dairy cows. Anim. Feed Sci. Technol. 2011, 166-167, 254-264. [CrossRef]

35. Doreau, M.; Chilliard, Y.; Bauchart, D.; Michalet-Doreau, B.; Fléchet, J.; Lefaivre, R.; Legay, C.; Meyer, M.; Ollier, A. Influence of different fat supplements on digestibility and ruminal digestion in cows. Ann. Zootech. INRA/EDP Sci. 1991, 40, 19-30. [CrossRef]

36. Smits, M.C.J.; Monteny, G.J.; van Duinkerken, G. Effect of nutrition and management factors on ammonia emission from dairy cow herds: Models and field observations. Livest. Prod. Sci. 2003, 84, 113-123. [CrossRef]

(C) 2017 by the authors. Licensee MDPI, Basel, Switzerland. This article is an open access article distributed under the terms and conditions of the Creative Commons Attribution (CC BY) license (http:/ / creativecommons.org/licenses/by/4.0/). 